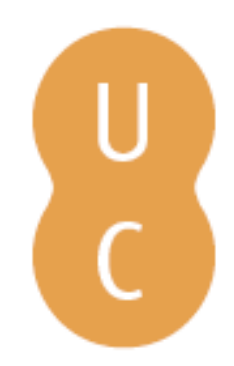

\title{
nommalina
}

\section{Assessing the effect of education on subjective well-being in Portugal: a study of mediating effects}

Autor(es): $\quad$ Pereira, Maria da Conceição; Martins, Daniel

Publicado por: Imprensa da Universidade de Coimbra

URL

persistente: URI:http://hdl.handle.net/10316.2/38156

DOI: $\quad$ DOI:http://dx.doi.org/10.14195/978-989-26-1039-9_10

Accessed : $\quad$ 26-Apr-2023 10:31:54

A navegação consulta e descarregamento dos títulos inseridos nas Bibliotecas Digitais UC Digitalis, UC Pombalina e UC Impactum, pressupõem a aceitação plena e sem reservas dos Termos e Condições de Uso destas Bibliotecas Digitais, disponíveis em https://digitalis.uc.pt/pt-pt/termos.

Conforme exposto nos referidos Termos e Condições de Uso, o descarregamento de títulos de acesso restrito requer uma licença válida de autorização devendo o utilizador aceder ao(s) documento(s) a partir de um endereço de IP da instituição detentora da supramencionada licença.

Ao utilizador é apenas permitido o descarregamento para uso pessoal, pelo que o emprego do(s) título(s) descarregado(s) para outro fim, designadamente comercial, carece de autorização do respetivo autor ou editor da obra.

Na medida em que todas as obras da UC Digitalis se encontram protegidas pelo Código do Direito de Autor e Direitos Conexos e demais legislação aplicável, toda a cópia, parcial ou total, deste documento, nos casos em que é legalmente admitida, deverá conter ou fazer-se acompanhar por este aviso.

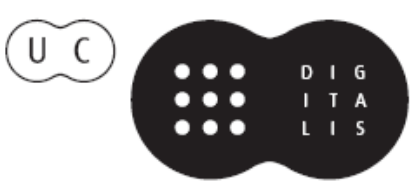


IMPRENSA DA UNIVERSIDADE DE COIMBRA

COIMBRA UNIVERSITY PRESS

\section{ASSESSMENT \\ METHODOLOGIES}

ENERGY, MOBILITY AND OTHER

REAL WORLD APPLICATION

\section{PEDRO GODINHO \\ JOANA DIAS}

EDITORS

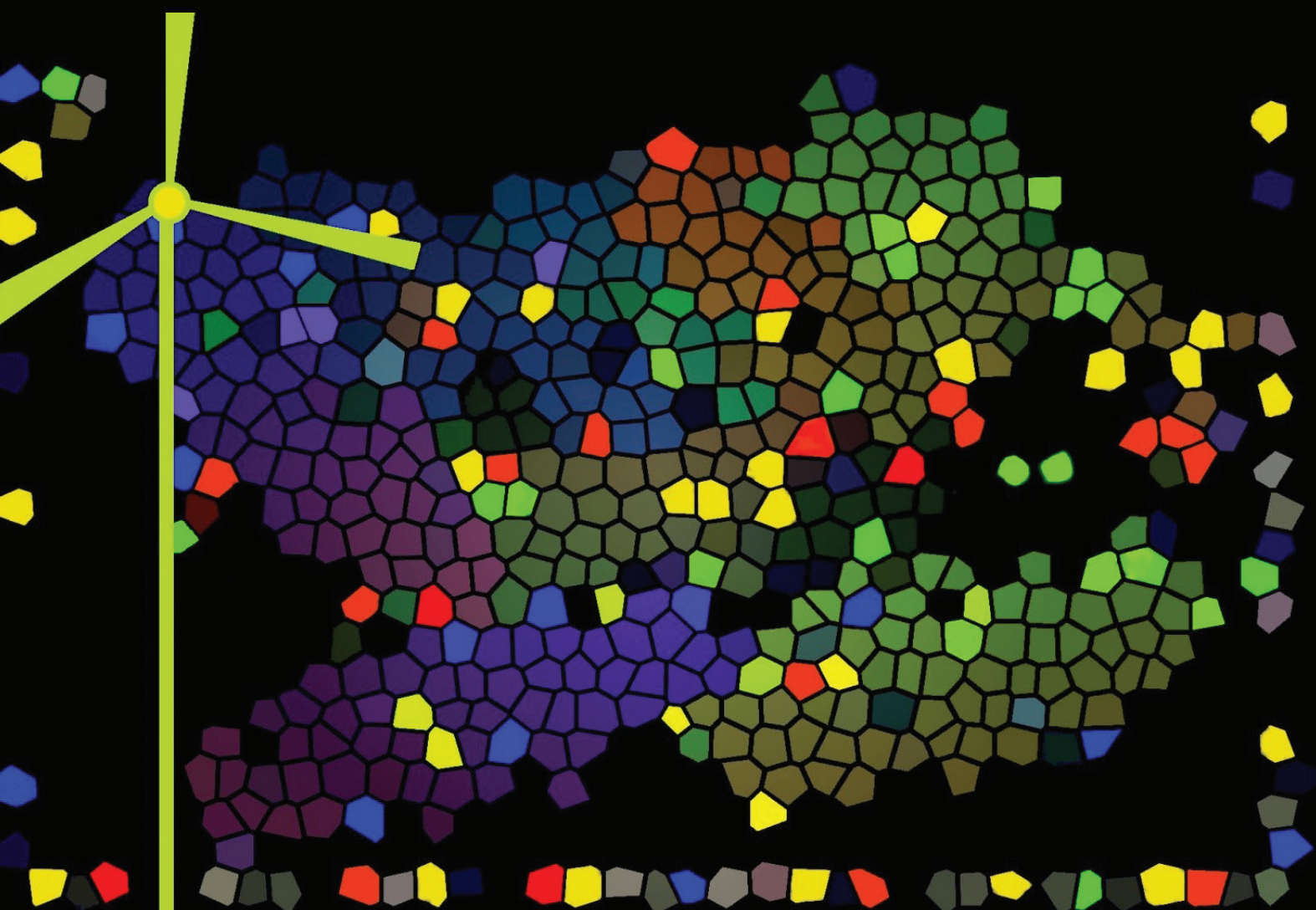




\title{
ASSESSING THE EFFECT OF EDUCATION ON SUBJECTIVE WELL-BEING IN PORTUGAL: A STUDY OF MEDIATING EFFECTS
}

\author{
Maria da Conceição Pereira ${ }^{1,2}$ and Daniel Martins ${ }^{1}$
}

\begin{abstract}
Research on happiness has shown that individuals derive utility from material as well as from non-material factors, from which some useful policy implications have been derived. Since education has not received the attention we believe it deserves within this literature, we aim at contributing to fill in this gap by assessing the effects of education on subjective well-being, thus raising awareness for the importance of investing in education. Accordingly, in this study we conduct an analysis of the mechanisms that transmit the effect of education into subjective well-being, focusing on Portugal, to take into account country specificities, and using data from the European Social Survey. In order to test such mechanisms, we add to a baseline regression, which includes the education level, a large set of potential mediating variables to test whether education affects SWB through the following channels: 1. Higher lifetime earnings; 2 . Higher professional status; 3. Less risk of unemployment; 4. Higher social capital, and 5. Better health. The analysis shows that most of the considered variables contribute to carry the effects of education into subjective well-being. This is evidenced by a reduction of the coefficients of the education variables following the introduction of each mediator in the regression, thus confirming the hypothesized channels of transmission. Moreover, we find that education does not exert a direct effect on well-being, that secondary education provides a wider range of benefits than higher education, and that the human capital theory is not enough to account
\end{abstract}

\footnotetext{
1 University of Coimbra, Faculty of Economics

2 GEMF

E-mails: mpereira@fe.uc.pt, uc2010131267@student.uc.pt
} 
for all the mechanisms transmitting the effect of education into subjective well-being in Portugal.

Keywords: Education, Subjective well-being, Happiness, Life satisfaction, Portugal

\section{Introduction}

Several authors have argued that results of research on the economics of happiness should be used to support public policy (e.g. Diener and Seligman, 2004; Frey, 2008; Helliwell, 2003; Layard, 2005). Some go as far as to call for a national system of well-being indicators. For instance, Diener and Seligman (2004: 2) wrote that such a system "would supplement and enhance [economic or other current social indicators'] value by placing them within an over-arching framework of well-being, underscoring the shortcomings of economic indicators. [...] The purpose of the production of goods and services and of policies in areas such as education, health, the environment, and welfare is to increase well-being. Therefore, well-being is the common desired outcome, and it follows directly that society should measure this outcome to provide a common metric for evaluating policies".

In fact, emphasis on well-being is important because there seems to be a pronounced gap between the information contained in traditional indicators of economic performance like GDP, and what matters for common people's well-being (Stiglitz et al., 2009). The economics of happiness challenges the traditional economic thinking by relying on the principle that the best way to find out what is really important for individuals is to ask them, thus using survey-based indicators of subjective well-being (hereafter SWB). These indicators reveal peoples' affective (pleasant and unpleasant feelings) and cognitive (satisfaction with life) evaluations of their lives. In so doing, this research has been able to foster the debate on the determinants of individual's well-being, showing that individuals derive utility from material and non-material factors, including volunteering (e.g. Meier and Stutzer, 2006), social relations (e.g. Pugno, 2007; Powdthavee, 
2008), religion (e.g. Clark and Lelkes, 2009), good governance (e.g. Frey and Stutzer, 2000) and the environment (e.g. Brereton et al., 2008). These insights suggest a broader notion of utility than conventional economics, thereby raising awareness for the need to pursue various goals, beyond those typically related to economic performance, and reshaping individuals and policy makers' preferences towards welfare enhancing choices.

The economics of happiness research has been producing valuable contributions to help derive policy implications in several domains. For instance, Di Tella et al. (2001) have shown that a 1-percentage point increase in the unemployment rate is compensated for, in terms of well-being, by a 1.7-percentage-point decrease in the inflation rate, implying that the misery index wrongly ascribes the same importance to the two causes of economic discomfort. Since unemployment has a more devastating effect on SWB, this result suggests that, in the trade-off between unemployment and inflation, more emphasis should be put on unemployment reduction policies. Another interesting example of a policy insight obtained from happiness research results from finding that the costs of unemployment go well beyond the loss of income (Winkelmann and Winkelmann, 1998). This suggests that policies meant to help individuals find a job would provide advantages beyond the traditional unemployment benefit, which does not compensate unemployed individuals for the psychological costs of unemployment, such as the loss of self-esteem (cf. Frey et al., 2002). Still another example, meaningful for our study, was provided by Oreopoulos (2005), showing how compulsory school laws increase lifetime wealth, health and happiness. Other findings with relevance for policy making are reviewed in Diener and Seligman (2004).

Education is one of the determinants usually included in happiness regressions ${ }^{3}$. However, there is no consensus about its net effect. This puts the economics of happiness in a fragile position in terms of policy inferences concerning investment in education. Some studies find a

3 Dolan et al. (2008) and Diener et al. (1999) provide extended surveys concerning the determinants of SWB, including education. Others, like Frey and Stutzer (2002), Myers and Diener (1995) and Diener and Seligman (2004) do not cover education as a main determinant of SWB. 
positive association between education and subjective well-being (e.g. Blanchflower and Oswald, 2004), whilst others find a negative relationship (e.g. Caporale et al., 2009). Moreover, the sign and strength of this link is frequently associated with a country's stage of development (e.g. Veenhoven, 1994), or with characteristics of the population, like income (Diener et al. 1993), or job status (Clark and Oswald, 1994).

Moreover, most of these studies have given education a secondary role, and studied it amongst many other variables. So far education has not been given the central stage role it deserves, most likely because researchers accept that its effects are mainly transmitted through income (Layard, 2005), thereby diverting their attention to the latter. Some exceptions are Botha (2014), Chen (2012), Ferrante (2009), and Salinas et al. (2011), which focus on mediating effects in the relationship between education and SWB. Even so, these papers take partial looks at those mechanisms and miss on undertaking a systematic effort to dissect all possible mechanisms.

Our purpose is then to contribute to fill in this gap in the literature, by undertaking a systematic analysis of the role of education in influencing well-being. Therefore, in contrast to previous studies that focus on a single or reduced set of mediating variables, we investigate the potential mediating role of a large set of variables that may help carry education's effects into SWB. Following the literature, we will test whether education affects SWB through the following channels: 1. Higher lifetime earnings; 2. Higher professional status; 3. Less risk of unemployment; 4. Higher social capital, and 5. Better health. These indirect effects stem from individuals apprehending education as an investment good, in the sense that by putting in both material and non-material efforts into education in the present, returns will emerge in the future, which again can be of a material and non-material nature. Alternatively, education can be seen as a consumption good, thus being enjoyed for its intrinsic value. Therefore, we also investigate whether education has a direct effect on SWB.

Many governments around the world have upheld a political agenda that recognizes the benefits of education (Michalos, 2008). Portugal is one of the OECD countries that has made more progress in improving 
the baseline qualifications of its population. This has been crucial since Portugal has had one of the worst records in terms of attainment rates for secondary and tertiary education. In 2012, the proportion of working-age adults (25-64 year-olds) whose highest level of attainment was upper secondary education was $19 \%$, which contrasts with the OECD average of $44 \%$, and the proportion of working-age adults with a tertiary diploma was $19 \%$ compared to the OECD average of 33\% (OECD, 2014). Nevertheless, Portugal has made an impressive progress in recent years. Portugal spent $5.9 \%$ of its GDP on education in 2009, compared to $4.9 \%$ in 1995 (OECD, $2012)^{4}$, and is one of the OECD countries that have shown more progress in improving the level of education of its population. The proportion of adults that have not attained upper secondary education decreased from $81 \%$ in 2000 to $62 \%$ in 2012 (OECD, 2014). In 2012 the proportion of 25-34 year-olds with at least an upper secondary education was 58\% and the proportion of 55-64 year-olds with a similar education level was only $20 \%$; equally, the proportion of 25-34 year-olds with tertiary education was $28 \%$, while the proportion of 55-64 year-olds with that same level was only $11 \%$ (OECD, 2014). This marked cross-generational difference leads to the expectation that Portuguese educational attainment will significantly improve over the years. Given the tough financial constraints that threaten to jeopardize these efforts and achievements, it becomes important to discuss which dividends education brings about, namely in terms of well-being, and in particular to inform the Portuguese authorities about the education's role.

We thus undertake this analysis for Portugal using data from the European Social Survey (ESS). Our analysis and empirical strategy can be extended /replicated to all of the countries included in the used dataset. Nevertheless, our focus on Portugal enables us to take into account country specificities. Given that the institutional context conditions the results, country-specific analysis are more suited to substantiate country specific policy recommendations.

\footnotetext{
4 This figure decreased to $5.5 \%$ in 2011. See Santiago (2012) for a list of measures that lead to a reduction in resources available to education in Portugal due to the economic crisis.
} 
The remainder of the paper is structured in a straightforward way. In section 2 we provide a brief survey of the literature focusing on the channels through which education exerts its effects on SWB; in section 3 we present the data and empirical strategy; in section 4 we present and discuss the estimation results; and in section 5 we conclude.

\section{Previous work/research}

Although education is seen as vital for societies, its role on well-being is not undisputed from an individual's point of view. A positive relationship between education and individual SWB has been documented by many authors (e.g. Blanchflower and Oswald, 2004; Botha, 2014; Chen, 2012; Delhey, 2004; Di Tella, 2003; Ferrer-i-Carbonell, 2005). Nonetheless, others find a negative effect of education on SWB (e.g. Caporale et al. 2009; Clark and Oswald, 1994, 1996). More education is commonly associated with longer working schedules, more stressful professions, higher dispersion of income and higher job expectations, which can upset the positive effects of education. More education is further responsible for distress in case of job loss (Clark and Oswald, 1994). Even the process of acquiring education is stressful and costly. Authors such as Veenhoven (2010) and Ferrante (2009) believe that beyond a certain threshold level, education may lose its significance, possibly because getting an education might involve costs that outweigh its benefits. Ferrante (2009) considers that real life opportunities commonly fall short of peoples' aspirations and finds that, beyond a certain level of education (secondary education for Italy), further education fuels socioeconomic aspirations (education rises people's earnings and job expectations, for example), in such a way as to depress SWB.

That education is more strongly related to well-being in poor countries is supported by Ferrer-i-Carbonell (2005), Veenhoven (1994) and Hartog and Oosterbeek (1997), and for individuals with lower income is evidenced by Diener et al. (1993).

Many of those who find a positive effect of education on SWB posit that such effect is exerted through indirect channels. From these different 
studies it is possible to identify mechanisms such as higher income, higher employability, rapid promotions, more secure jobs, social integration and increased health. For example Diener (1993) finds that once income is controlled for the effect of education becomes insignificant. Similarly, Helliwell (2002) found a small effect of education on SWB, after controlling for participation in social activities, health, trust in people, and higher income.

The more popular channels are grounded on the theory of human capital (Becker, 1964; Schultz, 1960). According to this theory, education adds to the stock of human capital, thereby promoting productivity. This leads to a higher income earning capacity and employability, which, in turn, leads to high-wage and high benefit jobs. Other than contributing to individuals' future returns by increasing their stock of capital, education may promote future earnings and employability by acting as a signal to the labour market, informing potential employers about workers' abilities, which are unobserved by them. This alternative idea has become known as signalling theory (Spence, 1973). In addition, this signal helps matching the most capable workers to the jobs that are more adequate to them, thereby promoting their well-being. Likewise, improved information and knowledge acquired through schooling increase labour market search efficiency (Haveman and Wolfe, 1984).

Education has played a central role in explaining growth. Within economic growth theory, the benefits of education are seen as deriving from an accumulation of human capital, which acts as a fundamental input to production and, thus, to output growth in the long run, as well as from a boost in total factor productivity, which operates as a driving force for growth (Teixeira, 2014). The increased labour market search efficiency, fostered by education, can also be seen as offering a growth driver. Matching workers to jobs where their productivity is the highest enhances their productivity, and this also serves the general interest of society, since a better allocation of resources leads to growth. Growth feeds back into the individual, since living in more developed environments boosts individual happiness (cf. Stevenson and Wolfers, 2008). For a long time many researchers and policy makers conformed to the 
impotence of public policy to foster happiness by promoting living standards, due to the observation that in many industrialized countries real per capita income, which is the main proxy for material well-being, has risen markedly since World War II, while average well-being has not. This finding has become known as the Easterlin paradox (Easterlin, 1974, 1995). Recently, however, a reassessment of the Easterlin paradox by Stevenson and Wolfers (2008) established a very strong relationship between SWB and growth.

The above perspectives support the role of education in facilitating the access to better quality jobs. These have multifaceted characteristics, in the sense that they are associated with higher wages, higher job status, and less vulnerability to unemployment, amongst others. Earnings' potential has been particularly emphasized, together with occupational status (e.g. Diener, 1999; Teixeira, 2014). In this context it is interesting to note that Portugal is the OECD country that exhibits the highest wage gain from attaining university-level degree $(70 \%$ as compared to the OECD average of 59\%, according to the latest data, 2012). Furthermore, there is a large body of evidence that a higher level of education leads to a lower risk of unemployment, from academic (e.g. Cuñado and de Gracia, 2012), as well as from international institutions. For instance, the OECD Education at a Glance (2013) reports that the unemployment rate in Portugal, between 2008 and 2011, among 25-64 year-olds without an upper secondary education, raised from $7.6 \%$ to $13.3 \%$ (the OECD average increased from $8.8 \%$ to $12.6 \%$ ); while among $25-64$ year-olds with tertiary education it increased from $5.8 \%$ to $8.0 \%$ (the OECD average increased from $3.3 \%$ to $4.8 \%)$.

Recently, attention has also been given to the role of social capital in channelling the benefits of education into well-being. Social capital has been defined as "networks together with shared norms, values and understandings that facilitate cooperation within or among groups" (Côté and Healy, 2001: 41). It is common to group the social resources that enable such a cooperation in the following dimensions: social networks, participation in social activities, involvement in civic activities and trust (Nieminen et al., 2008). A vast number of studies has documented the 
effect of education on social capital. For example Helliwell and Putman (2007) go so far as to say that education is the most important predictor of some forms of social capital. The effect of social capital on well-being is also well known (e.g. Han et al., 2013; Powdthavee, 2008; Pugno, 2007; Winkelmann, 2009). The indirect effect of education on SWB via social capital is dealt with by Helliwell (2002) and Chen (2012). Böhnke and Kohler (2008: 15) also recognizes that "educational skills are not only an (increasingly) important prerequisite for labour market integration, but also form the basis for social integration and participation in a modernized world".

For instance, through education individuals gain access to a vast network of people, which broadens their minds, thereby promoting well-being (cf. Chen, 2012). One of the indirect effects of education on SWB postulated by Helliwell (2002) flows through social connectedness, proxied by participation in social activities, namely church attendance, and membership in voluntary associations. According to Helliwell (2002), trust in people is another benefit that can carry the effects of education into SWB. Chen (2012) argues that education increases happiness by enhancing ones capacity to get involved with the world, not only family and neighbourhood, but the outside world as well, thereby becoming more open-minded about other cultures, thus broadening ones' horizons, which brings positive feelings. Chen (2012) focuses on specific forms of social capital, which are social networks (proxied by the number of acquaintances and contacts with family members during last New Year's vacation) and cosmopolitanism (captured by international travel experience and frequency with which one talks about international issues). $\mathrm{He}$ finds that these mediating factors are more important in explaining the relationship between education and SWB than income, in some Asian countries, except for China, for which income plays a more important role, supposedly due to China's relative low level of personal income.

The effect of education on health is also quite popular (e.g. Hartog and Oosterbeek, 1997; Oreopoulos, 2007). The rationale is that more educated individuals adopt more healthy lifestyles. In other words, they "are assumed to be more efficient producers of health; they have less 
unhealthy habits and visit their doctor when required" (Hartog and Oosterbeek, 1997: 2). In parallel, education contributes to the acquisition of information, and provides an advantage in the choice of less hazardous occupations and locations (Haveman and Wolfe, 1984). The effect of education on SWB through its effect on health is tackled by Gerdtham and Johannesson (2001).

In contrast to these indirect effects, education can provide utility per se. There are individuals who value the acquisition of knowledge independently of leveraging it into future benefits, and others obtain utility from attending school, as a form of entertainment (Lazear, 1977). While some studies do not find a direct effect of education on SWB (e.g. Helliwell, 2002), others detect such an effect (e.g. Blanchflower and Oswald, 2004; Cuñado and de Gracia, 2012; Salinas et al., 2011). Cuñado and de Gracia (2012) interpret the effect of education on SWB, after controlling for income, labour status, and health, as evidence of a self-confidence or self-esteem effect of education. We note, however, that the differences across studies often derive from the authors' subjective appreciation of the size of the coefficients of the education variables, as well as from omitted factors.

Most of the studies on the benefits of education focus on marketed effects of schooling, but Haveman and Wolfe (1984) identify a vast number of non-marketed effects, such as better marriage, child quality, consumer choice efficiency, crime reduction, social cohesion, amongst others. Likewise, Diener (1999: 293) recognizes that "education may contribute to SWB by allowing individuals to make progress toward their goals or to adapt to changes in the world around them", and Botha (2014) point to the role of education in providing life skills to avoid public shame, in rising social-status, and prestige. Sabates and Hammond (2008) provide a good review of the impact of education on well-being, covering less popular effects, such as self-esteem, self-efficacy, and risk of depression.

Education is also viewed as a positional good (e.g. Botha, 2014; Helliwell and Putman, 2007; Salinas et al., 2011), since it provides a differentiation device, thereby conferring social status and advantage in job competition. No matter whom people compare themselves with, be 
it region-wise (Helliwell and Putman, 2007), income-wise (Botha, 2014) or other, acquiring this differentiation provides a stimulus to individual's well-being.

\section{Methodology / Data and empirical strategy}

The dataset that we use to study the relationship between education and SWB is from the European Social Survey. This is a cross-national survey that has been conducted every two years in more than 30 European countries since 2001. As mentioned previously, only Portuguese data will be used. The study will consider the most recent three rounds, which refer to 2008, 2010 and 2012.

We adopt the following model for our baseline specification:

$W B_{i}^{*}=\alpha+\beta \cdot E D U_{i}+\gamma \cdot X_{i}+\delta_{t}+\varepsilon_{i}$

where $W B_{i}^{*}$ is the well-being level reported by individual $i$, which acts as a proxy for the true individual well-being WB and is measured by the answer to the question "All things considered, how satisfied are you with your life as a whole nowadays?". Answers range from 0 to 10 , where 0 means extremely dissatisfied and 10 means extremely satisfied 5 . EDU is education in the formal sense of the term, thus measured by the level of education attainment ${ }^{6}$.

$X$ is a vector of control variables, including gender (men being the reference category), age, and marital status ${ }^{7}, \delta$ is a time effect (a dummy

5 This measure was chosen because life satisfaction is less responsive to short-term circumstances (Helliwell, 2002) than happiness. However, experiments using the question "Taking all things together, how happy would you say you are?", to proxy well-being, converged to similar results.

${ }^{6}$ Seventeen categories were combined into three: basic education (reference category), comprising no education level, basic - levels 1,2 and 3, and vocational qualifications diploma courses of level 2; secondary education, which also includes vocational qualifications diploma courses of level 3 and technological specialization courses; and higher education, including polytechnic and university programmes at the bachelor's level or equivalent, post graduate programmes, including masters and doctoral degree.

7 The category "divorced" also includes individuals legally separated. The reference category is single. 
variable for each round), and $\varepsilon_{i}$ is the error term, also capturing non-available factors. Since our dependent variable is measured on an ordinal scale, the model is estimated as ordered probit, in which the true individual well-being is the latent variable.

Our empirical strategy consists of adding to this baseline specification factors expected to mediate the effect of education on SWB, and thus estimate the following model:

$$
W B_{i}^{*}=\alpha+\beta \cdot E D U_{i}+\gamma \cdot X_{i}+\theta \cdot H_{i}+\delta_{t}+\varepsilon_{i}
$$

where $H$ may stand for any one of such mediating variables. We will test a considerable number of mediators and predict the following:

Hypothesis 1: Education enhances SWB by raising earnings.

Hypothesis 2: Education enhances SWB by improving job status.

Hypothesis 3: Education enhances $\mathrm{SWB}$ by reducing the risk of unemployment.

Hypothesis 4: Education enhances SWB by boosting social capital.

Hypothesis 5: Education enhances SWB through its positive effect on health.

Table A1 in the appendix presents a detailed description of the explanatory variables, arranged according to the hypothesis being tested ${ }^{8}$. Here we briefly summarize the proxies used for each mediator. Earnings is proxied by the individual's household total income, computed in equivalent terms. That is, an adjustment is undertaken to consider economies of scale in consumption within the household.

Job status, referring to the position in which a worker is placed in the professional ladder, will be proxied by a set of variables, including workers having a supervisory role, autonomy in organizing own daily work, and capacity to influence management decision.

As to the third hypothesis, both current and past unemployment will be tested. Current unemployment includes those who are both actively looking for a job and those who are not. Past unemployment is measured considering two time horizons, a short-term unemployment spell, referring

8 Table A2 displays summary statistics of all variables and Tables A3 to A6 present correlation coefficients between the different proxies considered in hypothesis 2 to 5 . 
to a past experience of unemployment between 3 and 12 months long, and a long-term unemployment spell, referring to a past unemployment experience lasting 12 months or more.

As discussed in the previous section, social capital is a multifaceted concept, which does not have a universal measurement. Despite this, three aspects of social capital are commonly identified. Drawing on prior research, we will proxy such established aspects of social capital as follows. Social participation and social networks will be measured by the frequency of social meetings, by having or not someone to discuss intimate and personal matters, by social activity in general, and by religious activity. Civic engagement considers whether individuals voted in the last election, other civic participation (such as having worked in a political party), and perceptions of safety in the neighbourhood. Trust will focus in people and will encapsulate a perception not only of trust but of fairness and helpfulness as well, as detailed in the appendix.

The fifth hypothesis will be tested using self-reported health and disabling health problems.

By adding these potential mediators to estimations we expect the education coefficients to decrease. This will be evidence that part of the effect of education on SWB is mediated by such factors.

One last procedure will consist of analysing more comprehensive models. Some of these are meant to inspect whether there exists a direct effect of education on SWB, or whether the effect is exclusively exerted through indirect factors. In order to do that, we run a regression comprising variables from all hypothesis.

After deleting individuals that have missing values in any of the used variables we are left with 2785 observations.

\section{Empirical Results}

Tables 1 to 5 present the estimation results for different specifications, meant to test hypothesis 1 to 5 , respectively. The results of the estimation 
of the baseline specification are repeatedly shown in column 1 of all tables for comparison purposes.

Model 1 shows that gender has no effect on life satisfaction in Portugal, which contrasts with most countries where women seems to be happier than men. A possible explanation is that Portuguese women have a higher participation in the labour market than in other developed countries, and this may deteriorate their well-being, especially around motherhood period. As in most studies, there is a U-shaped relationship between life satisfaction and age. Compared to being single, being married positively contributes to life satisfaction'; whereas being divorced or separated, as well as being widowed, negatively impacts on life satisfaction, results which conform to expectations. As to the education variables, we observe that they are both statistically significant, and in particular that individuals with a higher education level are the ones reaching higher satisfaction.

Model 2 reports the results of testing hypothesis 1 . We accomplish this by regressing a model with $\mathrm{H}=$ income. Expectedly, income has a positive effect on SWB. Adding income to the baseline regression reduces the education variables coefficients in a remarkable way. What is even more striking is the reduction of the higher education coefficient, which suggests that the advantage from having a higher education comes exclusively from attaining a higher income. This is in accordance with the fact reported in section 2 that the net income gain from attaining a university-level degree is indeed very high in Portugal (the highest in OECD). Hence, we probably would not have found such a huge effect of income on the education role in influencing SWB in other OECD countries.

\footnotetext{
${ }^{9}$ In some of the coming models we note that the statistical significance of this variable is not upheld. This may be due to mediation effects, but we will not conjecture about it since it is not the focus of our study.
} 
Table 1: Hypothesis 1

\begin{tabular}{lll}
\hline & Model 1 & Model 2 \\
\hline Gender (man) & $0.0221[0.0405]$ & $-0.0150[0.0409]$ \\
Age & $-0.0067^{* * * *}[0.0014]$ & $-0.0056^{* * * *}[0.0014]$ \\
Age squared & $0.0003^{* * * * *}[0.0000]$ & $0.0003^{\text {***** }}[0.000]$ \\
Married & $0.1140^{*}[0.0597]$ & $0.0521[0.0603]$ \\
Divorced & $-0.2684^{* * * *}[0.0832]$ & $-0.2635^{* * * *}[0.0832]$ \\
Widowed & $-0.184^{* * *}[0.0823]$ & $-0.1515^{*}[0.0825]$ \\
Secondary Educ. & $0.2511^{\text {**** }}[0.0590]$ & $0.1698^{* * * *}[0.0600]$ \\
Higher Educ. & $0.3534^{* * * *}[0.0697]$ & $0.1476^{*}[0.0753]$ \\
Income & & $0.2386^{* * * * *}[0.0331]$ \\
Pseudo $\mathrm{R}^{2}$ & 0.0194 & 0.0237 \\
\hline
\end{tabular}

Estimations also include round dummies. Standard errors are shown in parenthesis. Single, double and triple asterisks indicate significant coefficients at the $10 \%, 5 \%$ and $1 \%$ levels, respectively.

Table 2 presents the estimation results for the models that include the variables regarding job status. Model (3) shows that individuals who are responsible for supervising the work of some employees report higher levels of satisfaction with life. Interestingly, a higher degree of responsibility in this respect seems to be neutral to life satisfaction. Higher responsibility in supervising workers brings more decision latitude, but expanding options bring about psychological decision costs, namely in gaining information to support decisions and in confronting one's own bad decisions (Ferrante, 2009). The negative feelings thus gained may cause stress and worries that neutralize any eventual positive effect that professional status could confer. Furthermore, the education coefficients decrease with respect to model 1 , suggesting a mediation effect, in particular for higher education. Models (4) and (5) inform us that autonomy in deciding how individuals' daily work is organized and capacity to influence management decision exert a positive effect on well-being and decrease the education coefficients relative to model (1) - these effects are more pronounced than in model (3). We can see that, bringing together these three proxies, in model (6), does not lead to a much steeper decline in education coefficients, and only the highest degree of autonomy and the proxy "influence" keep its statistical significance. This may result, at least in part, from these variables capturing overlapping features of job 
status (Table A3, in the appendix, shows high correlation coefficients between autonomy and influence). Thus, we conclude that there is some evidence that, in Portugal, education promotes well-being by providing a higher job status.

Table 3 reports estimations that test education as a risk of unemployment reduction device. Model (7), which adds current unemployment to the baseline regression, confirms the usual result that unemployment is detrimental to life satisfaction. By observing a modest reduction in the education coefficients we also learn that education somehow boosts SWB by reducing the risk of unemployment. Models (8) and (9) consider past unemployment, of a short and long term nature, respectively. We can see that past unemployment experience only depresses life satisfaction scores and mediates the relationship between education and well-being in the case of a long unemployment spell. Model (10) combines current with past long unemployment to find out that they both seem relevant in explaining SWB, but they do not seem to carry different effects from education into SWB, since the drop in the coefficients of education is not much different from the ones observed in models (8) and (9) (this is probably related to the fact that these variables are correlated; Table A5, in the appendix, shows a correlation coefficient of 0.55 between current unemployment and long-term past unemployment). We believe that, overall, these results endorse hypothesis 3, although in a mild manner.

In Table 4, models (11) to (19), we include social capital to test whether education acts through it to improve SWB in Portugal. We can see that individuals more socially integrated score higher in satisfaction with life, no matter what dimension of social capital we test for. In addition, we see that the coefficients of the education variables slightly decrease in most models. In models (11) through (14) we test for the effect of social networks and participation, by using as proxy for this dimension of social capital the frequency of social meetings, having someone to discuss intimate and personal matters, social activity and religious activity, respectively. We find a significantly positive effect on SWB of all such proxies for social networks and participation. This dimension of 
social capital also seems to play a mediating role in the SWB-education relation, although attending religious services seems to be an exception. The strongest reduction in the education coefficients occurs when participation in social activities is introduced in model (13).

Table 2: Hypothesis 2

\begin{tabular}{|c|c|c|c|c|c|}
\hline & Model 1 & Model 3 & Model 4 & Model 5 & Model 6 \\
\hline Gender (man) & $0.0221[0.0405]$ & $0.0057[0.0410$ & $-0.0179[0.0410]$ & $-0.0106[0.0408]$ & $-0.0218[0.022]$ \\
\hline Age & $-0.007^{\text {***** }}[0.0014]$ & $-0.0069^{\text {**** }}[0.0014]$ & $-0.0068^{* * *}[0.0014]$ & $-0.0071^{\text {*冰* }}[0.0014]$ & $-0.0071^{* * * *}[0.007]$ \\
\hline Age squared & $0.0003^{\text {****** }}[0.0000]$ & $0.0003^{* * *}[0.0000]$ & $0.0003^{\text {**** }}[0.0000]$ & $0.0003^{* * *}[0.0000]$ & $0.0003^{* * * *}[0.000]$ \\
\hline Married & $0.1140 *[0.0597]$ & $0.1123^{*}[0.0597]$ & $0.1073^{*}[0.0597]$ & $0.1019 *[0.0597]$ & $0.1035^{*}[0.060]$ \\
\hline Divorced & $-0.268^{\text {**** }}[0.0832]$ & $-0.266^{\text {**** }}[0.0832]$ & -0.2796 *** $[0.0833]$ & $-0.2854^{\text {*a*k }}[0.0833]$ & $-0.2828^{* * * *}[0.083]$ \\
\hline Widowed & $-0.1824 *[0.0823]$ & $-0.1775^{* *}[0.0824]$ & $-0.1738^{* *}[0.0824]$ & $-0.1696^{* * *}[0.0824]$ & $-0.1670 *$ * $[0.082]$ \\
\hline Secondary Educ. & $0.2511^{\text {**** }[0.0590]}$ & $0.2326^{* * * *}[0.0594]$ & $0.2084^{\text {**** }}[0.0593]$ & $0.2100 * * * 0.0592]$ & $0.2055^{\text {**** }}[0.060]$ \\
\hline Higher Educ. & $0.3534^{* * * *}[0.0697]$ & $0.3109^{* * * *}[0.0714]$ & $0.2682^{* * * *}[0.0711]$ & $0.2705^{* * *}[0.0710]$ & $0.2418^{* * * *}[0.072]$ \\
\hline Workers sup. - some & & $0.1944^{* * * *}[0.0703]$ & & & $0.0906[0.074]$ \\
\hline Workers sup. - many & & 0.1114 [0.0981] & & & $0.0084[0.101]$ \\
\hline Autonomy - low & & & $0.2158^{* * * *}[0.0606]$ & & $0.0350[0.083]$ \\
\hline Autonomy - medium & & & $0.2975^{\text {**** }}[0.0579]$ & & $0.0895[0.080]$ \\
\hline Autonomy - high & & & $0.3745^{\text {**** }}[0.0577]$ & & $0.1775^{\text {*** }}[0.083]$ \\
\hline Influence - low & & & & $0.2515^{* * *}[0.0514]$ & $0.2234^{* * * *}[0.071]$ \\
\hline Influence - medium & & & & $0.3225^{* * *}[0.0544]$ & $0.2508^{* * * *}[0.074]$ \\
\hline Influence - high & & & & $0.3488^{* * * *}[0.0568]$ & $0.1983^{\text {** }}[0.082]$ \\
\hline Pseudo $\mathrm{R}^{2}$ & 0.0194 & 0.0201 & 0.0231 & 0.0238 & 0.0245 \\
\hline
\end{tabular}

Estimations also include round dummies. Standard errors are shown in parenthesis. Single, double and triple asterisks indicate significant coefficients at the $10 \%, 5 \%$ and $1 \%$ levels, respectively. 
Table 3: Hypothesis 3

\begin{tabular}{|c|c|c|c|c|c|}
\hline & Model 1 & Model 7 & Model 8 & Model 9 & Model 10 \\
\hline Gender (man) & $0.0221[0.041]$ & $0.0130[0.041]$ & $0.0234[0.041]$ & $0.0149[0.041]$ & $0.0112[0.041]$ \\
\hline Age & $-0.0067^{* \text { **** }}[0.001]$ & $-0.0081^{\text {*** }}[0.001]$ & $-0.0070^{* * *}[0.001]$ & $-0.0080^{\text {*** }}[0.0014]$ & $-0.0085^{* * * *}[0.000]$ \\
\hline Age squared & $0.0003^{\text {***** }}[0.000]$ & $0.0002 * * 0.000]$ & $0.0003^{\text {**** }}[0.000]$ & $0.0002^{\text {***** }}[0.000]$ & $0.0002^{\text {**** }}[0.000]$ \\
\hline Married & $0.1140^{*}[0.060]$ & $0.1034^{*}[0.06]$ & $0.1134^{*}[0.060]$ & $0.0959[0.060]$ & $0.0960[0.060]$ \\
\hline Divorced & $-0.2684^{* * * * *}[0.083]$ & $-0.2614^{\text {**** }}[0.083]$ & $-0.2656 * * 0.083]$ & $-0.2765^{* * * *}[0.083]$ & $-0.2675^{* * * *}[0.083]$ \\
\hline Widowed & $-0.1824^{* *}[0.082]$ & $-0.1993^{* *}[0.082]$ & $-0.1827 * * 0.082]$ & $-0.2040 *[0.083]$ & $-0.2071^{\text {**** }}[0.083]$ \\
\hline Secondary Education & $0.2511^{\text {**** }}[0.059]$ & $0.2285^{* * *}[0.059]$ & $0.2543^{\text {**** }}[0.059]$ & $0.2142^{* * * *}[0.060]$ & $0.2137^{\text {**** }}[0.060]$ \\
\hline Higher Education & $0.3534^{\text {**** }}[0.070]$ & $0.3185^{* * *}[0.070]$ & $0.3598^{\text {**** }}[0.070]$ & $0.3119^{\text {**** }}[0.071]$ & $0.3040^{\text {**** }}[0.070]$ \\
\hline Current unemployment & & $-0.3528^{* * * *}[0.066]$ & & & $-0.2697^{* * * *}[0.079]$ \\
\hline Past unempl. - short & & & $-0.1098[0.069]$ & & \\
\hline Past unempl. - long & & & & $-0.2610^{* * *}[0.058]$ & $-0.1425^{\text {** }}[0.069]$ \\
\hline Pseudo $\mathrm{R}^{2}$ & 0.0194 & 0.0218 & 0.0196 & 0.0211 & 0.0221 \\
\hline
\end{tabular}

Estimations also include round dummies. Standard errors are shown in parenthesis. Single, double and triple asterisks indicate significant coefficients at the $10 \%, 5 \%$ and $1 \%$ levels, respectively.

Although this reduction in coefficients is not comparable with that observed in model (2), the increase in the pseudo- $\mathrm{R}^{2}$ in model (13) is more expressive than in model (2), suggesting that adding social participation improves the explanatory power of the model more than income. A possible explanation for this is that education is already capturing the contribution of income to SWB, whereas social capital adds new dimensions of individuals' needs, and this agrees with the literature that finds a more significant role for post-materialistic concerns than for materialist concerns on SWB (e.g. Delhey, 2004; Böhnke and Kohler, 2008).

Models (15) through (17), which test for civic engagement, give evidence of a positive contribution to SWB for all the proxies considered, as well as a mediating role for voting and civic participation, while no significant changes are detected in the education coefficients when security in the neighbourhood is added to the baseline regression. In Model (18) we observe that trust exerts a mediating role in the SWBeducation relation. In model (19) we include all dimensions of social capital (including one proxy of each dimension), and find that the drop 
in the education coefficients is quite remarkable ${ }^{10}$. Nevertheless, when compared to model (2), we find that the mediating effect of income is still more powerful than that of social capital.

Finally, regression results from testing hypothesis five are displayed in Table 5, models (20), (21) and (22). In model (20) we can see that if individuals have a better perception about their health, their SWB scores are significantly higher. We also note that the explanatory power of this regression increases considerably. Additionally, education coefficients decrease significantly when this variable is added. Similarly, those who have problems that hamper daily activity are less satisfied with their lives. The mediating role of the latter, however, is smaller than that of perceived health. The combination of the two variables adds little explanation power to the estimation and in terms of mediation, the latter variable does not seem to add any new channel of influence of education on SWB.

Table 4: Hypothesis 4 (social networks and participation)

\begin{tabular}{|c|c|c|c|c|c|}
\hline & Model 1 & Model 11 & Model 12 & Model 13 & Model 14 \\
\hline Gender (man) & $0.0221[0.041]$ & $0.0063[0.041]$ & $0.0275[0.041]$ & $0.0025[0.041]$ & $0.0449[0.041]$ \\
\hline Age & $-0.0067^{\text {**** }}[0.001]$ & $-0.0064^{* * * *}[0.001]$ & $-0.0061^{\text {**** }}[0.001]$ & $-0.0059^{\text {***** }}[0.001]$ & $-0.0072^{* * * *}[0.001]$ \\
\hline Age squared & $0.0003^{* * * *}[0.0000]$ & $0.0003^{* * * *}[0.0000]$ & $0.0003^{* * *}[0.000]$ & $0.0003^{* * *}[0.000]$ & $0.0003 * *[0.000]$ \\
\hline Married & $0.1140 *[0.060]$ & $0.1262^{\text {*** }}[0.060]$ & $0.0896[0.060]$ & $0.1086 *[0.060]$ & $0.1071 *[0.060]$ \\
\hline Divorced & $-0.2684^{* * * *}[0.083]$ & $-0.2689^{* * *}[0.083]$ & $-0.2643^{* * * *}[0.083]$ & $-0.2693^{\text {***** }}[0.083]$ & $-0.2694^{\text {**** }}[0.083]$ \\
\hline Widowed & $-0.1824^{* * *}[0.082]$ & $-0.1608 *[0.082]$ & $-0.1656^{\text {**** }}[0.082]$ & $-0.1677^{\text {*** }}[0.082]$ & $-0.1981^{\text {** }}[0.083]$ \\
\hline Secondary Educ. & $0.2511^{\text {**** }}[0.059]$ & $0.2267^{\text {****** }}[0.059]$ & $0.2333^{\text {***** }}[0.059]$ & $0.2060 * * * * 0.059]$ & $0.2620^{* * * *}[0.059]$ \\
\hline Higher Educ. & $0.3534^{* * * *}[0.070]$ & $0.3283^{\text {***** }}[0.070]$ & $0.3235^{\text {**** }}[0.070]$ & $0.2974^{* * * *}[0.070]$ & $0.3646^{\text {**** }}[0.070]$ \\
\hline Social meeting - medium & & $0.1948^{* * * * * *}[0.066]$ & & & \\
\hline Social meeting - high & & 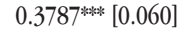 & & & \\
\hline Someone to talk to & & & $0.4421^{\text {***** }}[0.065]$ & & \\
\hline Social act. - same & & & & 0.3170 **** $[0.041]$ & \\
\hline Social act. - more & & & & $0.3402^{* * * *}[0.080]$ & \\
\hline Relig. act. - sometimes & & & & & $0.1012 *[0.043]$ \\
\hline Relig. act. - often & & & & & 0.1736 *** [0.081] \\
\hline Pseudo $\mathrm{R}^{2}$ & 0.0194 & 0.0233 & 0.0232 & 0.0246 & 0.0201 \\
\hline
\end{tabular}

10 Including all variables used to measure social capital leads the secondary and higher education variables to drop to 0.1619 and 0.1947 , respectively, and the $\mathrm{R}^{2}$ to rise to 0.0355 . 
Table 4 (continued): Hypothesis 4 (civic engagement; trust)

\begin{tabular}{|c|c|c|c|c|c|}
\hline & Model 15 & Model 16 & Model 17 & Model 18 & Model 19 \\
\hline Gender (man) & $0.0160[0.041]$ & $0.0173[0.041]$ & $0.0044[0.041]$ & $0.0100[0.041]$ & $-0.0126[0.041]$ \\
\hline Age & $-0.0078^{* * * * *}[0.001]$ & $-0.0065^{* * * *}[0.001]$ & 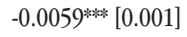 & -0.0066 **** $[0.001]$ & 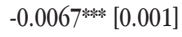 \\
\hline Age squared & $0.0003^{* * * *}[0.000]$ & $0.0003^{\text {***** }}[0.000]$ & $0.0003^{\text {**** }}[0.000]$ & $0.0003^{\text {***** }}[0.000]$ & $0.0003^{* * *}[0.000]$ \\
\hline Married & $0.0978[0.060]$ & $0.1138^{*}[0.060]$ & $0.1201^{*}[0.060]$ & $0.1080^{*}[0.060]$ & $0.0898[0.060]$ \\
\hline Divorced & $-0.2747^{* * * *}[0.083]$ & $-0.2725^{* * *}[0.083]$ & $-0.2493^{\text {***** }}[0.083]$ & $-0.2563^{\text {**** }}[0.083]$ & $-0.2631^{\text {***** }}[0.083]$ \\
\hline Widowed & $-0.1906^{* * *}[0.082]$ & $-0.1833^{* *}[0.082]$ & $-0.1651^{\text {䗇 }}[0.082]$ & $-0.1539 *[0.082]$ & $-0.1487^{*}[0.083]$ \\
\hline Secondary educ. & 0.2369 ***** [0.059] & $0.2367^{\text {****** }}[0.060]$ & 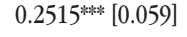 & $0.2268^{\text {***** }}[0.059]$ & $0.1748 *$ * $[0.060]$ \\
\hline High education & $0.3110^{\text {***** }}[0.071]$ & $0.3245^{\text {**** }}[0.071]$ & $0.3497^{*} * *_{*}^{*}[0.070]$ & $0.2973^{* * * * *}[0.070]$ & $0.2137^{* * * *}[0.071]$ \\
\hline Social act. - same & & & & & $0.3035^{* * *}[0.041]$ \\
\hline Social act. - more & & & & & $0.3054 *$ * $* 0.080]$ \\
\hline Vote & $0.1815^{\text {**** }}[0.044]$ & & & & $0.1441^{* * * *}[0.044]$ \\
\hline Civic participation & & $0.1113^{*}[0.058]$ & & & \\
\hline Neighbourhood - safe & & & $0.2133^{* * * *}[0.045]$ & & \\
\hline $\begin{array}{l}\text { Neighbourhood - very } \\
\text { safe }\end{array}$ & & & $0.2894^{* * *}[0.072]$ & & \\
\hline Trust & & & & $0.0862 * * *[0.011]$ & $0.0816 * * \%[0.011]$ \\
\hline Pseudo $\mathrm{R}^{2}$ & 0.0209 & 0.0197 & 0.0217 & 0.0244 & 0.0302 \\
\hline
\end{tabular}

Estimations also include round dummies. Standard errors are shown in parenthesis. Single, double and triple asterisks indicate significant coefficients at the $10 \%, 5 \%$ and $1 \%$ levels, respectively.

Table 5: Hypothesis 5

\begin{tabular}{|c|c|c|c|c|}
\hline & Model 1 & Model 20 & Model 21 & Model 22 \\
\hline Gender (man) & $0.0221[0.041]$ & $-0.0354[0.041]$ & $-0.0016[0.041]$ & $-0.0352[0.041]$ \\
\hline Age & $-0.0067^{* * * *}[0.001]$ & $-0.0000[0.002]$ & $-0.0035^{* *}[0.001]$ & $0.0002[0.001]$ \\
\hline Age squared & $0.0003^{\text {*** }}[0.000]$ & $0.0003^{* * *}[0.000]$ & $0.0003^{* * * *}[0.000]$ & $0.0003^{\text {****** }}[0.000]$ \\
\hline Married & $0.1140^{*}[0.060]$ & $0.0770[0.060]$ & $0.0872[0.060]$ & $0.0722[0.060]$ \\
\hline Divorced & $-0.2684^{\text {**** }}[0.083]$ & $-0.2991^{\text {**** }}[0.083]$ & $-0.3131^{* * * *}[0.083]$ & $-0.3138^{* * * *}[0.083]$ \\
\hline Widowed & $-0.1824^{* *}[0.082]$ & $-0.2005^{* * *}[0.082]$ & $-0.1765^{* *}[0.082]$ & $-0.1948^{* *}[0.082]$ \\
\hline Second. educ. & $0.2511 * * *[0.059]$ & $0.1787^{* * *}[0.059]$ & $0.2105^{* * *}[0.059]$ & $0.1735^{\text {***** }[0.059]}$ \\
\hline Higher educ. & $0.3534^{* * *}[0.070]$ & $0.2673^{\text {*** }}[0.070]$ & $0.3154^{\text {**** }}[0.070]$ & $0.2656^{\text {***** }}[0.070]$ \\
\hline Health - fair & & $0.5109^{* * *}[0.059]$ & & $0.3946^{\text {***** }}[0.067]$ \\
\hline Health - good & & $0.7930^{* * *}[0.064]$ & & $0.6354^{* * * *}[0.076]$ \\
\hline D. H. P - some & & & $-0.4408^{*}$ *** $[0.055]$ & $-0.2000^{\text {**** }}[0.062]$ \\
\hline D. H. P - a lot & & & $-0.6703^{* * * *}[0.094]$ & $-0.3117^{* * * *}[0.105]$ \\
\hline Pseudo $\mathrm{R}^{2}$ & 0.0194 & 0.0322 & 0.0276 & 0.0334 \\
\hline
\end{tabular}

Estimations also include round dummies. Standard errors are shown in parenthesis. Single, double and triple asterisks indicate significant coefficients at the $10 \%, 5 \%$ and $1 \%$ levels, respectively. 
As a whole, these findings support the five hypothesis we put forward. More specifically, we conclude that the first hypothesis is supported to a greater extent, seeing that income is the mediating factor leading to a higher reduction in the education coefficients. Since separately adding variables from each of the five hypothesis reduces the education coefficients, but do not annul their significance, we went further to investigate whether education effects are totally or only partially mediated. In addition, since we have seen in model (2) that the monetary factor is not enough to exhaust the education effects on SWB, we aim to check the role of non-monetary factors in channelling such affects. Table 6 presents several comprehensive models that enables us to investigate these issues.

Model (23) assembles all five hypothesis. From each set of measures associated with each of the five hypothesis we retained the one with the highest mediation effect ${ }^{11}$. When we consider all transmission mechanisms, we observe that the effect of education on SWB is no longer significant, which indicates that there is no direct effect of education on well-being. Other experiments considering all hypothesis, using different variables or using all proxies examined in this study, produced similar results. Considering different sets of mediators and using data for 18 OECD countries, Helliwell (2002: 24) also found that the coefficients of education have a low magnitude, inferring that the benefits of education "flow primarily through [...] participation, health, perceived trust, and higher income". However he did not conduct a proper examination of mediation. In contrast, Cuñado and de Gracia (2012), using ESS data for Spain and controlling for income, main activity, and health status, found that a very low level of education (not completed primary) keeps its significance, and interpret this as a direct effect. However, in view of our results, we believe that this effect could be picking up other omitted mediators.

11 The exception to this refers to unemployment. The variable with the highest mediating effect was long-term past unemployment, but we retained instead current unemployment, because this is the typical measure included in standard happiness estimations, and the difference in mediating effects for the two variables, measured by the drop in education coefficients, is quite small. 
Models (24) through (27) include income and the set of significant variables from each of the hypothesis 2 to 5. In model (24) we can see that, after controlling for income, adding job status is not enough to drive secondary education to non-significance, but it is sufficient to annul higher education's significance. In models (25), (26) and (27) we can see a similar pattern when separately including unemployment, social capital and health, respectively. These results suggest that secondary education provides a wider variety of benefits than tertiary education. Finally, we realized that adding income, job status and unemployment is sufficient to drive the higher education variable to non-significance, but it is not enough to annul the secondary education's significance. This proves that the theory of human capital is not sufficient to account for all mechanisms transmitting the effect of education into SWB, given that the statistical significance of the secondary education coefficient indicates that this level of education provides benefits other than higher income, higher job status and less vulnerability to unemployment. Furthermore, this result is also evidence of the higher variety of benefits enabled by secondary education, as compared to higher education, suggesting that secondary education can provide benefits that go beyond materialistic aspects, namely by providing people with social resources and/or healthier lives, which promote well-being. Indeed, when adding perceived health or social capital to the latter specification the effect of secondary education disappears ${ }^{12}$. Using European Quality of Life survey data, Böhnke and Kohler (2008: 29) found a similar result when health was included in the regression, concluding that an important role of attaining secondary education is related to living in healthier conditions.

\section{Concluding Remarks}

Education has been left with an undeserved secondary role in the economics of happiness. Thus, a more thorough analysis of the role of

\footnotetext{
12 We do not report the results of such estimations for parsimony reasons.
} 
education is in need. We aimed in this study to contribute to fill in this void in the happiness literature. We have focused on Portugal, which is one of the OECD countries that has made more progress in improving the baseline qualifications of its population, though still lagging behind in terms of educational attainment. This occurs despite Portugal spending on education almost as much as the OECD average (5.9\% compares to the OECD average of $6.2 \%$ in 2009 ).

We have found that education has a positive impact on SWB and, more specifically, that having a higher education seems to pay off in terms of SWB. By observing the changes in the coefficients of the education variables we have been able to confirm all postulated hypothesis. I.e. that education enhances SWB by contributing to attain higher earnings, higher job status, less vulnerability to unemployment, more social resources, and better health.

In particular, we have realized that income is the factor that reduces education coefficients to a larger extent. Furthermore, we have realized that the drop in the coefficient of higher education, after controlling for income, is much larger than that of secondary education, almost levelling the latter. This result is in accordance with the outstanding earnings advantage for those with university-degree in Portugal. 
Table 6: Testing the direct and indirect effects of education on SWB

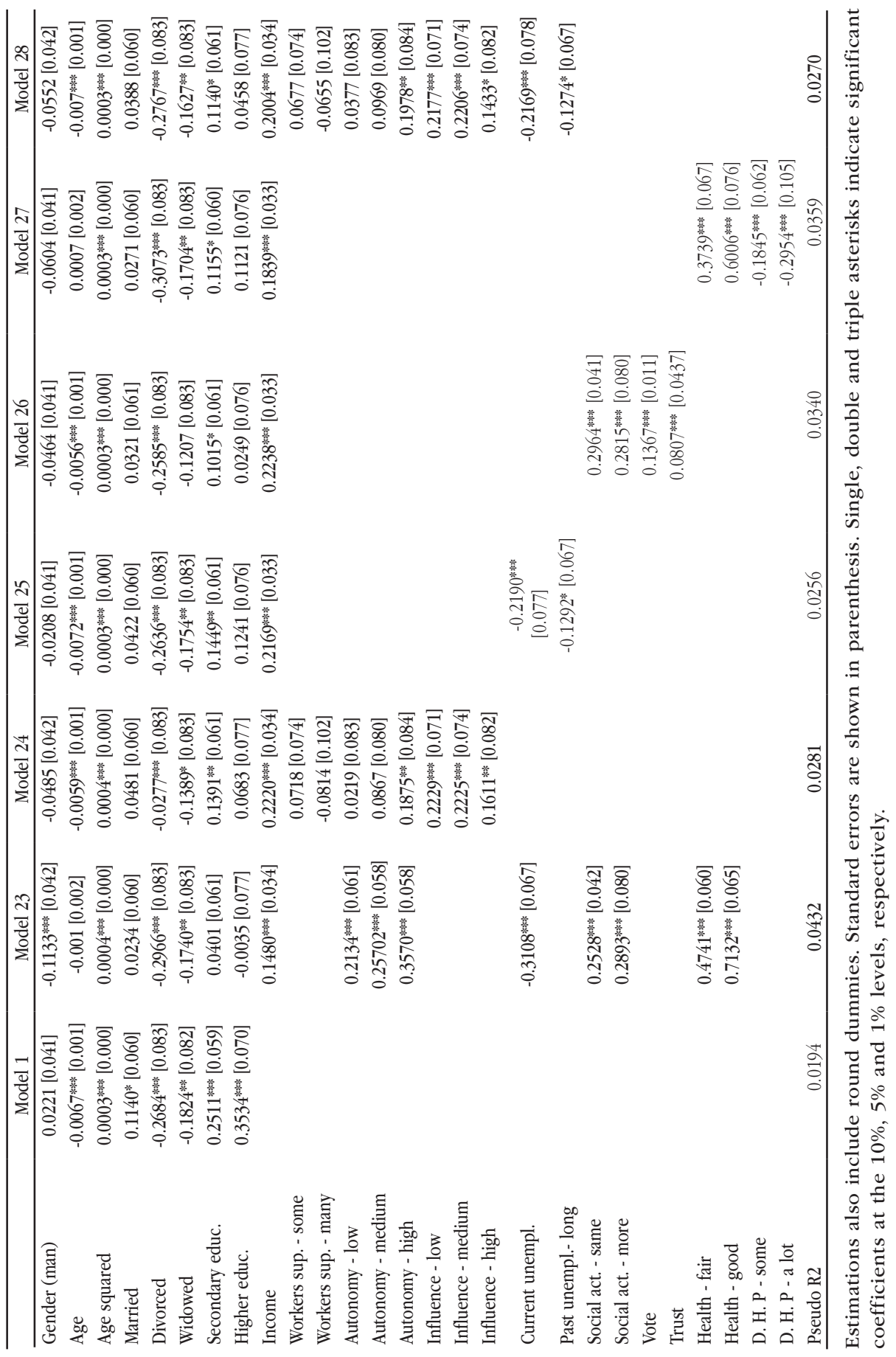


We note that the superior role of material factors is not a symptom of a developed country. As suggested by Chen (2012), monetary factors are likely to be more relevant in countries where material achievements have not been fulfilled for the general population, while non-monetary factors are likely to play a more crucial role in abundant societies. Chen (2012) showed that non-monetary factors, namely the number of interpersonal networks and the degree of cosmopolitanism, are much more important than income for some countries in East Asia. Still, this same study finds a superior contribution of income for China, and rationalizes it on the basis of being a country where personal income is generally low, thus playing a more important role for SWB.

However, we also found that social capital adds more explanatory power to the model than income, which barely alters the regression's pseudo- $\mathrm{R}^{2}$. Perceived health also gives a stronger contribution to explain SWB than income. In this respect Portugal shows evidence of a high income country. This is more in accordance with studies that account for a stronger relationship between income and life satisfaction in poor countries than in rich ones (e.g. Ferrer-i-Carbonell. 2005). In this vein, Delhey (2010) and Böhnke and Kohler (2008) found that individuals living in poor countries derive more satisfaction from material concerns, whereas individuals living in more affluent countries derive more satisfaction from post-materialistic concerns. In a study conducted using the ESS second round data (covering 20 European countries), Lima and Novo (2006) found that Portugal was the European country where objective variables (gender, age, household income, education level, and marital status) mattered the most to the prediction of SWB, namely when compared to subjective variables (perceived income, perceived health, and collectivist and individualistic values). We are thus confronted with mixed signals about Portugal's profile in terms of development stage.

In addition, given that we found that none of the considered factors separately exhausts the effects of education on SWB, we investigated whether the complete set accomplished that. I.e., we checked whether the education effects are totally or only partially mediated, and found that the effect of education on well-being in Portugal is exclusively ex- 
erted through indirect channels. Individuals value education for what it brings them, in terms of material and non-material rewards, not for itself.

Moreover, since the monetary factor alone is not sufficient to drive the education's coefficients to non-significance, we tested for each hypothesis after controlling for income. In this manner, when we added the set of variables used to test for each hypothesis, we learned that higher education loses its significance, while secondary education still keeps it. This suggests that secondary education can provide a wider variety of benefits than higher education. Even when we included all variables that can be associated with human capital theory, in model (28), that same pattern emerges. This proves that such a theory is not enough to account for the mediating effects of education in SWB in Portugal, and is further evidence of the higher variety of benefits enabled by secondary education, as compared to higher education. This result is quite remarkable, given that apart from validating the traditional focus on education, it reinforces its role by evidencing that individuals can derive utility from education in ways that are not usually emphasized in mainstream economics.

Our results support the focus of recent Portuguese governments in investing in education. In particular, in view of the results that show that the secondary level of education enables a wider variety of benefits, we feel inclined to say that public policy should focus its efforts in assuring that the population at least attains this level of education. A big step has already been taken by having extended compulsory school to twelve years since 2009. If young people "ignore or heavily discount future consequences when deciding to drop out of school [...] making school compulsory or offering incentives to stay in school may help improve lifetime outcomes" (Oreopoulos, 2007). However, much remains to be done. For instance, investment in the secondary level of education for the adult population needs to be reinforced. The program of education for adults has suffered with the financial problems that the country has gone through. A program of adult education called New Opportunities was established in 2005, but its restructuring since 2012 has been leading to a decrease in the offer of education for adults. The new centres for qualification and vocational education that replaced the New Opportunities' 
centres are still awaiting for financing and do not seem to be responding adequately to the needs of the adult population. Santiago et al. (2012) provide a list of policy recommendations directed at improving school outcomes in Portugal, within an OECD Report reviewing the implementation and use of assessment and evaluation procedures.

\section{References}

Becker, Gary S. (1964). Human Capital: A Theoretical and Empirical Analysis, with Special Reference to Education. University of Chicago Press, Ltd London. 1993, 3rd ed.5 for NBER.

Blanchflower, David G. and Oswald, Andrew J. (2004). Well-being over time in Britain and the USA. Journal of Public Economics, 88, 1359-1386.

Böhnke, Petra and Kohler, Ulrich (2008). Well-being and Inequality. WZB Discussion Paper. Social Science Research Center Berlin (WZB).

Botha, Ferdi (2013). Life Satisfaction and Education in South Africa: Investigating the Role of Attainment and the Likelihood of Education as a Positional Good. Social Indicators Research, 118(2), 555-578.

Brereton, Finbarr; Clinch, J. Peter and Ferreira, Susana (2008). Happiness, geography and the environment. Ecological Economics, 65 (2), 386-396.

Caporale, Guglielmo Maria; Georgellis, Yannis: Tsitsianis, Nicholas and Yin, Ya Ping (2009). Income and happiness across Europe: do reference values matter? Journal of Economic Psychology, 30(1), 42-51.

Chen, Wan-chi (2012). How Education Enhances Happiness: Comparison of Mediating Factors in Four East Asian Countries. Social Indicators Research, 106(1), 117-131.

Clark, Andrew E. and Oswald, Andrew (1994). Unhappiness and Unemployment. The Economic Journal, 104 (424), 648-659.

Clark, Andrew E. and Oswald, Andrew (1996). Satisfaction and Comparison Income. Journal of Public Economics, 61, 359-381.

Clark, Andrew and Lelkes, Orsolya (2009). Let us Pray: Religious Interactions in Life Satisfaction. Working Paper No. 2009-01, Paris School of Economics.

Côté, Sylvain and Healy, Tom (2001). The Well-being of nations. The role of human and social capital. Organization for Economic Co-operation and Development, Paris.

Cuñado, Juncal and de Gracia, Fernando Pérez (2011). Does Education Affect Happiness? Evidence for Spain. Social Indicators Research, 108(1), 185-196.

Delhey, Jan (2010). From Materialist to Post-Materialist Happiness? National Affluence and Determinants of Life Satisfaction in Cross-National Perspective. Social Indicators Research, 97, 65-84.

Delhey, Jan (2004). Life satisfaction in an enlarged Europe. Report for the European Foundation for the Improvement of Living and Working Conditions. Luxembourg: Office for Official Publications of the European Communities. 
Di Tella, Rafael; MacCulloch, Robert and Oswald, Andrew (2001). Preferences over Inflation and Unemployment: Evidence from Surveys of Happiness. American Economic Review 91(1), 335-341.

Diener, Ed; Sandvik, Ed; Seidlitz, Larry and Diener, Marissa (1993). The relationship between income and subjective well-being: Relative or absolute? Social Indicators Research, 28, 205-215.

Diener, Ed; Suh, Eunkook; Lucas, Richard and Smith, Heidi (1999). Subjective Well-being: Three Decades of Progress. Psychological Bulletin, 125 (2), 276-302.

Diener, Ed and Seligman, Martin (2004). Beyond Money: Toward an Economy of Well-Being. Psychological Science in the Public Interest, 5 (1), 1-31.

Di Tella, Rafael; MacCulloch, Robert and Oswald, Andrew J. (2003). The Macroeconomics of Happiness. Review of Economics and Statistics, 85(4), 809-27.

Dolan, Paul; Peasgood, Tessa and White, Mathew (2008). Do We Really Know What Makes us Happy? A Review of the Economic Literature on the Factors Associated with Subjective Well-being. Journal of Economic Psychology, 29 (1), 94-122.

Easterlin, Richard A. (1974). Does Economic Growth Improve the Human Lot? Some Empirical Evidence. In Nations and Households in Economic Growth: Essays in Honor of Moses Abramovitz, Paul A. David and Melvin W. Reder (Eds.), New York: Academic Press, 89125.

Easterlin, Richard A. (1995). Will Raising the Incomes of all Increase the Happiness of all?, Journal of Economic Behavior and Organization, 27 (1), 35-47.

Ferrante, Francesco (2009). Education, Aspirations and Life Satisfaction. Dipartimento di Scienze Economiche Università di Cassino. Working Paper 3/2009.

Ferrer-i-Carbonell, Ada (2005). Income and Well-being: an Empirical Analysis of the Comparison Income Effect. Journal of Public Economics, 89 (5-6), 997-1019.

Frey, Bruno S. and Stutzer, Alois (2002). What Can Economists Learn from Happiness Research? Journal of Economic Literature, 40 (2), 402-435.

Frey, Bruno S. and Stutzer, Alois (2000). Happiness, Economy and Institutions. The Economic Journal, 110(15), 918-938.

Frey, Bruno S. (2008). Felicidade: uma Revolução na Economia. Gradiva: Lisboa.

Gerdtham, Ulf-G. and Johannesson, Magnus (2001). The relationship between happiness, health, and socio-economic factors: Results based on Swedish microdata. Journal of Socio-Economics, 30, 553-557.

Han, Sehee; Kim, Heaseung and Lee, Hee-Sun (2013). A Multilevel Analysis of the Compositional and Contextual Association of Social Capital and Subjective Well-Being in Seoul, South Korea. Social Indicators Research, 111(1), 185-202.

Haveman, Robert H. and Wolfe, Barbara L. (1984). Schooling and Economic Well-Being: the role of nonmarket effects. The Journal of Human Resources, 19(3), 377-407.

Helliwell, John F. (2002/3?). How's life? Combining Individual and National Variables to Explain Subjective Well-being. Working Paper 9065, National Bureau of Economic Research.

Helliwell, John F. and Putman, Robert D. (2007). Education and Social Capital. Eastern European Journal, 33(1), 1-19.

Layard, Richard (2005). Happiness: lessons from a new science. Penguin Books: London.

Lazear, Edward P. (1977). Education: Consumption or Production? Journal of Political Economy, 85, 569-98. 
Lima, Maria Luísa and Novo, Rosa (2006). So far so good? Subjective and social well-being in Portugal and Europe. Portuguese Journal of Social Science, 5(1), 5-33.

Meier, Stephan and Stutzer, Alois (2006). Is Volunteering Rewarding in Itself?. Economica, 75 (297), 39-59.

Myers, David G. and Diener, Ed (1995). Who Is Happy? Psychological Science, 6(1), 10-19.

Nieminen, Tarja; Martelin, Tuija; Koskinen, Seppo; Simpura, Jussi; Alanen, Erkki; Härkänen, Tommi and Aromaa, Arpo (2008). Measurement and Socio-demographic Variation of Social Capital in a Large Population-based Survey. Social Indicators Research, 85, 405423.

OECD (2012). Education at a Glance 2012 - Country Note. OECD Publishing. http://dx.doi. org/10.1787/eag-2012-en. Accessed in 23/01/2015.

OECD (2014). Education at a Glance 2014: OECD Indicators, OECD Publishing. http:// dx.doi.org/10.1787/eag-2014-en. Accessed in 23/01/2015.

Powdthavee, Nattavudh (2008). Putting a Price Tag on Friends, Relatives, and Neighbours: Using Surveys of Life-Satisfaction to Value Social Relationships. Journal of SocioEconomics, 37(4), 1459-1480.

Pugno, Maurizio (2007). The subjective well-being paradox: a suggested solution based on relational goods. In Handbook on the Economics of Happiness, Luigino Bruni and Pier Porta (coord.), Elgar, 263-289.

Sabates, Ricardo and Hammond, Cathie (2008). The Impact of Lifelong Learning on Happiness and Well-being. Institute of Education, London.

Salinas-Jiménez, Maria del Mar; Artés, Joaquín and Salinas-Jiménez, Javier. 2010. Education as a Positional Good: A Life Satisfaction Approach. Social Indicators Research, 103(3), 409-426.

Santiago, Paulo; Donaldson, Graham; Looney, Anne and Nusche, Deborah (2012). OECD Reviews of Evaluation and Assessment in Education: Portugal 2012. OECD Publishing. http://dx.doi.org/10.1787/9789264117020-en. Accessed in 23/01/2015.

Schultz, Theodore W. (1961). Investment in Human Capital. American Economic Review, $51,1-17$.

Spence, Michael (1973). Job Market Signaling. The Quarterly Journal of Economics. 87(3), 355-374. 
Table A1: Description of the variables tested under the five hypothesis

\begin{tabular}{|c|c|}
\hline H1 & $\begin{array}{l}\text { come } \\
\text { Please tell me which letter describes your household's total income, after tax and } \\
\text { mpulsory deductions, from all sources? If you don't know the exact figure, please give } \\
\text { estimate. } \\
\text { t: Since intervals differ throughout the three rounds, the mid-term point of the income } \\
\text { terval bracket was standardized. In order to consider income in equivalent terms, it was } \\
\text { so divided by the square-root of the number of household members. This adjustment is } \\
\text { eant to consider economies of scale in consumption within the household. }\end{array}$ \\
\hline \multirow[t]{3}{*}{$\mathrm{H} 2$} & $\begin{array}{l}\text { Workers supervision } \\
\text { Q1: In your main job, do/did you have any responsibility for supervising the work of } \\
\text { other employees? } \\
\text { Q2: How many people are/were you responsible for? } \\
\text { Cat.: No (omitted category); some workers (1 to } 9 \text { ); many workers ( } 10 \text { or more). }\end{array}$ \\
\hline & $\begin{array}{l}\text { Autonomy } \\
\text { Q: How much the management at your work allows/allowed you to decide how your } \\
\text { own daily work is/was organised? } \\
\text { Cat: No autonomy (omitted category); low autonomy ( } 1 \text { to } 4) \text {; medium autonomy ( } 5 \text { to } \\
\text { 7); high autonomy ( } 8 \text { to } 10 \text { ). }\end{array}$ \\
\hline & $\begin{array}{l}\text { management decision } \\
\text { the management at your work allows/allowed you to influence policy } \\
\text { it the activities of the organisation? } \\
\text { nce (omitted category); low influence ( } 1 \text { to } 4 \text { ); medium influence ( } 5 \text { to } 7 \text { ); } \\
\text { ( } 8 \text { to } 10) \text {. }\end{array}$ \\
\hline \multirow[t]{2}{*}{$\overline{\mathrm{H} 3}$} & $\begin{array}{l}\text { Current unemployment } \\
\text { Q: Which of these descriptions applies to what you have been doing for the last } 7 \text { days? } \\
\text { In paid work; in education; unemployed and actively looking for a job; unemployed, } \\
\text { wanting a job but not actively looking for a job; permanently sick or disabled; retired; } \\
\text { in community or military service; doing housework, looking after children or other } \\
\text { persons. } \\
\text { Cat.: In paid work or other categories (reference category); unemployed (either looking } \\
\text { for a job or not). }\end{array}$ \\
\hline & $\begin{array}{l}\text { Past unemployment (short and long-term) } \\
\text { Q1: Have you ever been unemployed and seeking work for a period of more than } 3 \\
\text { months? } \\
\text { Q2: Have any of these periods lasted } 12 \text { months or more? } \\
\text { Cat.: Past short-term unemployment (yes to Q1 and no to Q2); past long-term } \\
\text { unemployment (yes to Q1 and yes to Q2). }\end{array}$ \\
\hline
\end{tabular}




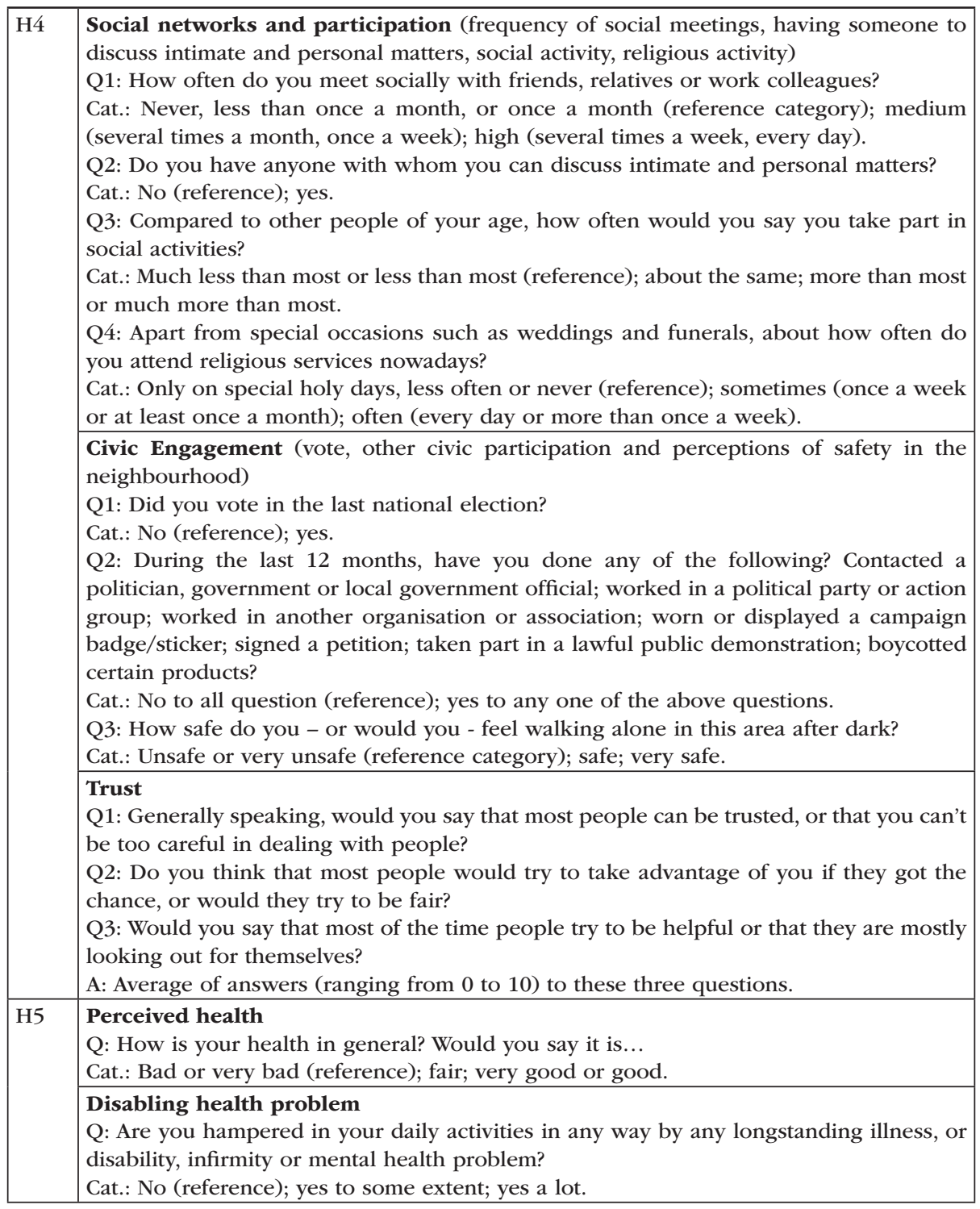


Table A2: Descriptive statistics (average/percentages)

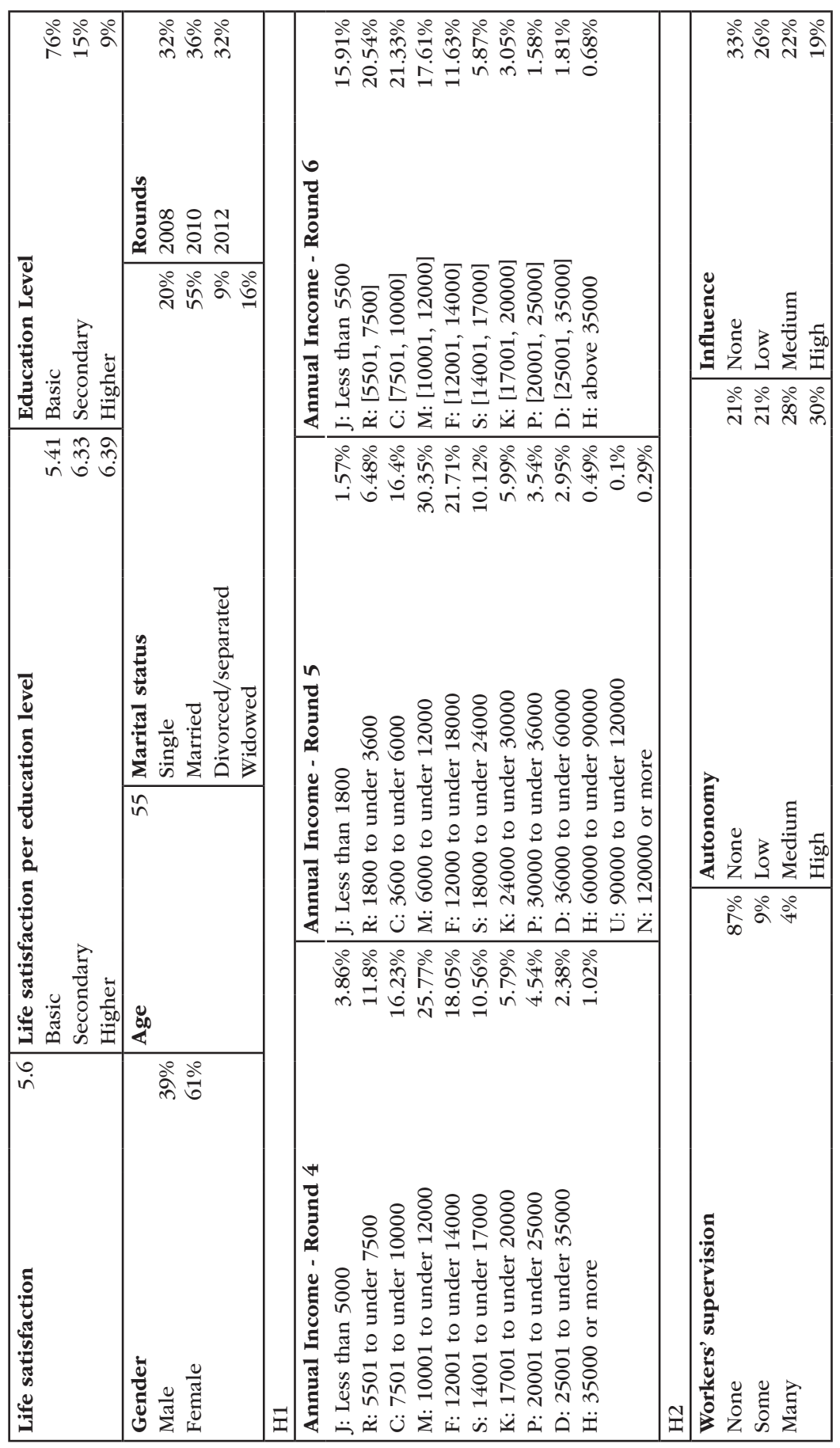


Table A2 (continued): Descriptive statistics (average/percentages)

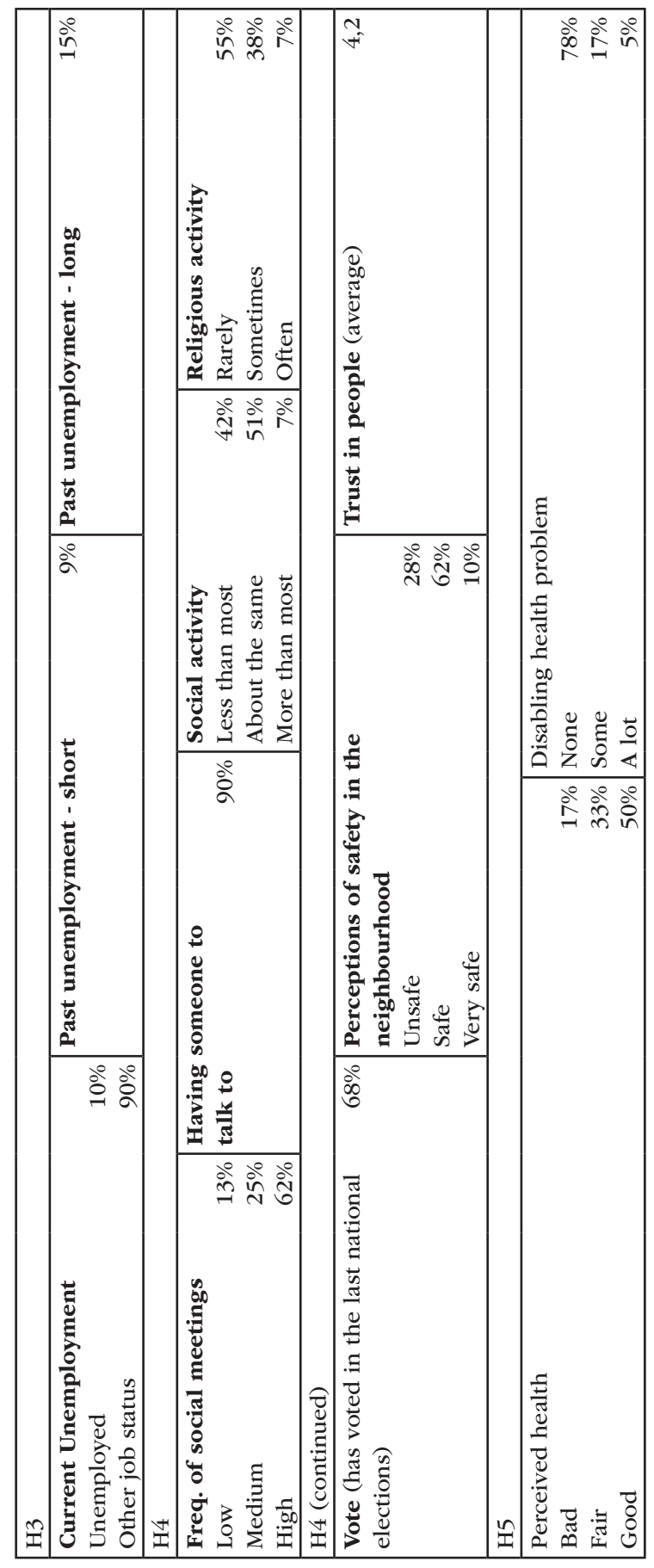


Table A3: Correlation coefficients - variables tested in $\mathrm{H} 2$

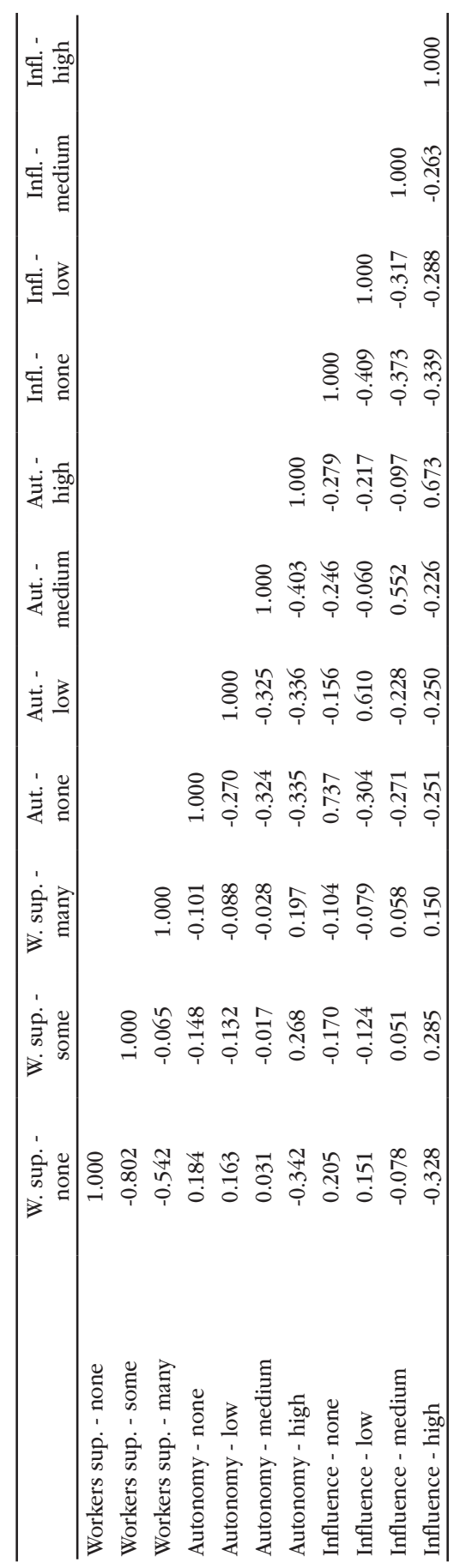


Table A4: Correlation coefficients - variables tested in H4

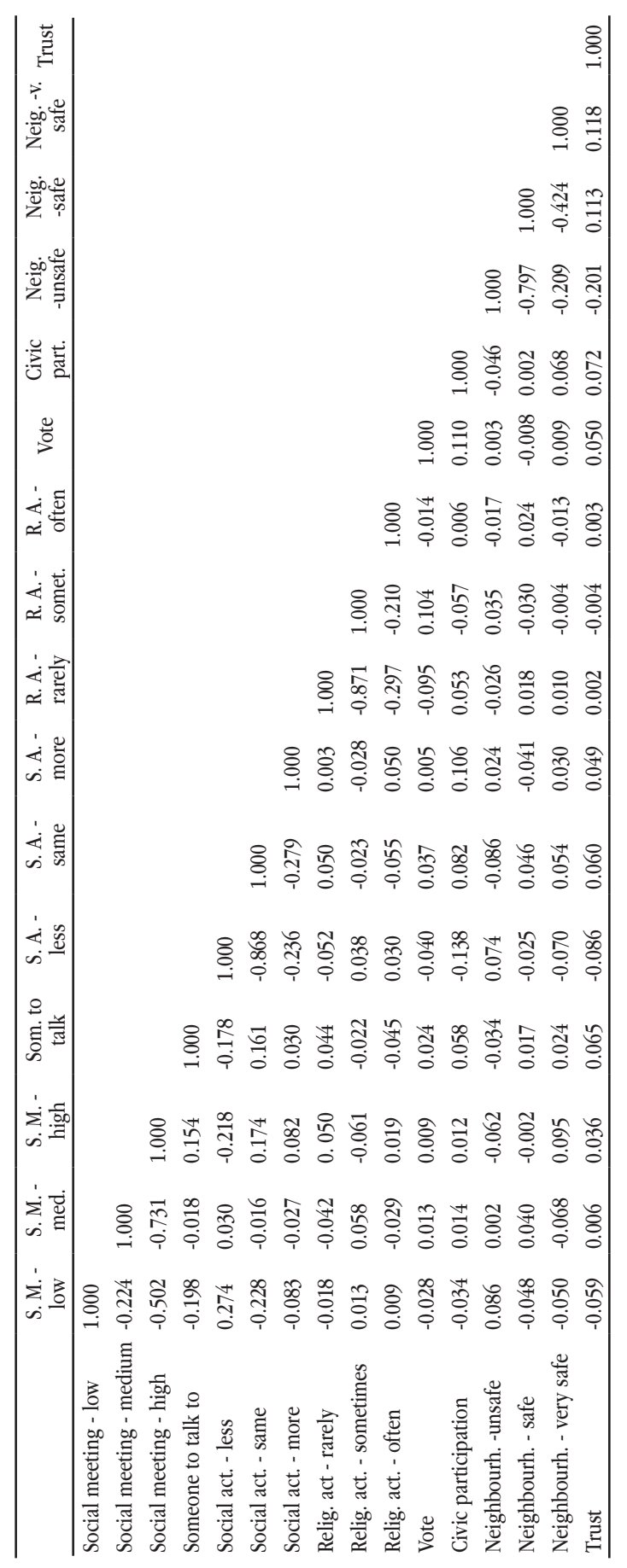


Table A5: Correlation coefficients - variables tested in $\mathrm{H} 3$

\begin{tabular}{cccc}
\hline & $\begin{array}{c}\text { Current } \\
\text { unemp. }\end{array}$ & Past. un.- short & Past. un.- long \\
\hline Current unemp. & 1.000 & & \\
Past unemp. - short & 0.143 & 1.000 & \\
Past unemp. - long & 0.551 & -0.130 & 1.000 \\
\hline
\end{tabular}

Table A6: Correlation coefficients - variables tested in $\mathrm{H} 5$

\begin{tabular}{lcccccc}
\hline & $\begin{array}{c}\text { Health - } \\
\text { bad }\end{array}$ & $\begin{array}{c}\text { Health - } \\
\text { fair }\end{array}$ & $\begin{array}{c}\text { Health - } \\
\text { good }\end{array}$ & $\begin{array}{c}\text { D. H. P - } \\
\text { none }\end{array}$ & $\begin{array}{c}\text { D. H. P - } \\
\text { some }\end{array}$ & $\begin{array}{c}\text { D. H. P - } \\
\text { a lot }\end{array}$ \\
\hline Health - bad & 1.000 & & & & & \\
Health - fair & -0.317 & 1.000 & & & & \\
Health - good & -0.452 & -0.703 & 1.000 & & & \\
D. H. P - none & -0.572 & -0.053 & 0.478 & 1.000 & & \\
D. H. P - some & 0.415 & 0.111 & -0.416 & -0.863 & 1.000 & \\
D. H. P - a lot & 0.379 & -0.097 & -0.193 & -0.415 & -0.101 & 1.000 \\
\hline
\end{tabular}


Série Investigação

Imprensa da Universidade de Coimbra

Coimbra University Press

2015

mais

Programa Operacional Regional do Centro

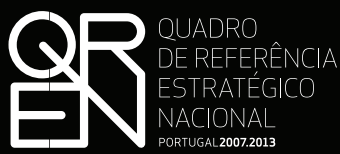

PORTUGAL 2007.2013

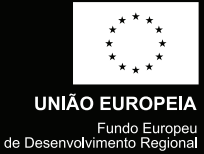

- $\mathbf{U}$

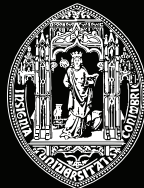

C •

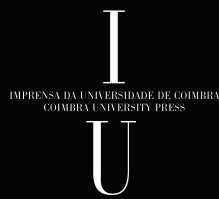

